\title{
E-Module Based on Local Wisdom Ngubat Padi Improves Students' Social Care Character
}

\section{Asrial1 ${ }^{*}$, Syahrial2 ${ }^{2}$, Dwi Agus Kurniawan ${ }^{3}$, Juwita Saputri ${ }^{4}$}

1,2,3,4 Fakultas Keguruan dan Ilmu Pendidikan, Universitas Jambi, Muaro Jambi, Indonesia

\section{ART ICLE INF O}

Article history:

Received June 28, 2021

Revised June 29, 2021

Accepted August 30, 2021

Available online November 25, 2021

Kata Kunci:

Modul Elektronik, Peduli Sosial, Respon

Keywords:

Electronic Modules, Social Care, Respons

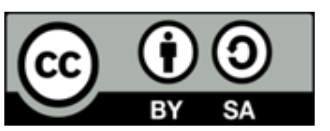

This is an open access article under the CC BY-SA license.

Copyright (@) 2021 by Author. Published by Universitas Pendidikan Ganesha.

\begin{abstract}
A B S T R A K
Penggunaan bahan ajar merupakan hal penting bagi seorang guru menyampaikan materi pembelajaran. Terlebih pemilihan bahan ajar yang salah dapat berpengaruh pada karakter siswa yang akan menjadi lemah. Penelitian ini bertujuan untuk menganalisis hubungan antara karakter peduli sosial yang diintegrasikan dengan modul elektronik berbasis kearifan lokal budidaya padi. Dengan metode penelitian menggunakan penelitian kuantitatif asosiatif, yang bertujuan untuk menghubungkan suatu indikator. Subjek penelitian adalah siswa kelas IV dengan teknik pengambilan sampel adalah total sampling. Instrumen pengumpulan data yang digunakan adalah angket. Analisis data menggunakan statistik deskriptif dengan menggunakan uji korelasi untuk mengetahui hubungan dari dua variabel. Hasil dalam penelitian ini adalah karakter sosial yang dimiliki siswa memiliki kategori baik, dilihat dari indikator karakter peduli sosial setelah menggunakan modul elektronik berbasis kearifan lokal, diperkuat dengan hasil korelasi yang diperoleh sebesar 0,969 dan menghasilkan hubungan yang positif. Maka dari itu penting bagi guru untuk mengimplementasikan modul elektronik berbasis kearifan lokal pada pembelajaran agar dapat menanamkan karakter peduli sosial pada siswa.
\end{abstract}

\section{A B S T R A C T}

The use of teaching materials is essential for a teacher to deliver learning materials. Moreover, the selection of the wrong teaching materials can affect the character of students who will become weak. This study aims to analyze the relationship between social care characters integrated with electronic modules based on local wisdom of rice cultivation. The research method uses associative quantitative research, which aims to link an indicator. The research subjects were fourth-grade students, with the sampling technique being total sampling. The data collection instrument used was a questionnaire. Data analysis used descriptive statistics by using a correlation test to determine the relationship between two variables. The results in this study are that the social character of the students has a suitable category, seen from the indicators of social care character after using an electronic module based on local wisdom, strengthened by the correlation results obtained by 0.969 and produces a positive relationship. Therefore, teachers need to implement electronic modules based on local knowledge in learning to instill social care characters in students.

\section{INTRODUCTION}

Education is a crucial role holder in a country because education can increase human resources (Sajnani \& Mayor, 2020; Tajvidi et al., 2014). Education is easy to understand in knowledge, skills, and attitudes to encourage someone to become disciplined (Eugenia et al., 2013; Maulana, 2021; Mehrtash et al., 2019). Education aims to foster physical and spiritual peaceful thinking so that students become better human beings (Kratz et al., 2019; Marhayani, 2016; Oswald-Egg \& Renold, 2021). Education is viewed from its presence in Indonesia and the goals that have urgency for the general public, then the quality of education in Indonesia should be able to increase. Education in the globalization era is the nation's integration that utilizes technology as a facility in learning to improve the quality of education (Bakırci et al., 2011; Chauhan, 2017; Lynch et al., 2021). Technology and education at this time are very closely related to each other. Both are parallel and have a goal which is to advance Indonesia. Education is an important issue today. Integrating humans and technology has led to extensive knowledge, including learning innovation in 
education (Bravo et al., 2015; Omotayo \& Haliru, 2020; Raja \& Nagasubramani, 2018). Knowledge of technology in education is quite extensive. Technology is used as an information driver and develops pedagogic competence (Almusawi et al., 2021; Astuti et al., 2021; Tondeur et al., 2019). A teacher's ability will also be more optimal with the presence of technology in education, as is the case in selecting learning media in the form of audio, visual, or technology-based audio-visual (Fu et al., 2019; Müller \& Wulf, 2020). However, the current problem is that many teachers still do not use technology in learning (Astalini et al., 2019; Ningsih \& Mahyuddin, 2021; Sadimin Sadimin et al., 2017). In addition, teachers find it challenging to develop technology-based learning media (Fisnani et al., 2020; Komikesari et al., 2020). Many classrooms do not use teaching materials such as electronic modules to see the character of students. Teachers prefer pre-existing learning materials (Astra et al., 2020; Raharjo et al., 2017). Lessons given to education in Indonesia are still lacking in using preferred media instead of innovations from teachers who make educational progress less suitable. It is necessary to provide complete information about learning by technological developments (Aprilia \& Suryadarma, 2020; Aufa et al., 2021). The number of obstacles, teachers must be creative in delivering learning materials to students by their respective portions of the number of subjects.

The learning media used by a teacher must, of course, be able to make it easier for information to be conveyed to students, especially the media used is easy to carry and not easily damaged, such as electronic modules (Logan et al., 2021; Seruni et al., 2020). Electronic modules engage media by utilizing technological devices and packaged in the electronic form to make it easier for teachers to deliver learning materials (Asrial et al., 2020; Herawati \& Muhtadi, 2018; Linda et al., 2018). For this reason, it is necessary to develop electronic-based modules. Electronic modules can build active students, concentration, and learning a chievement (Ilmi et al., 2021; Perdana et al., 2017). The application of electronic modules provides real learning to students. The system also makes it easier to access learning activities (Darmaji, Astalini, et al., 2019; Handayani et al., 2021). Learning activities provided using electronic modules must be of high quality. Learning does not deviate and has good values for students. Learning with values needs to be integrated using good media and methods and requires a creative teacher (Aina \& Tuti, 2020; Kaplan, 2018). As a teacher who conveys information in learning, he must convey the best possible information, allowing the teacher to operate technology (Başöz \& Çubukçu, 2014; Mahmoodi et al., 2019). Learning based on local wisdom or local culture is meaningful learning with good moral values for students. The values in learning local wisdom have to learn targets to reach students who can accept the values given in learning (Baker et al., 2021; Winther-Lindqvist, 2020). With the module as a learning medium, it will be easier for teachers to introduce local wisdom or local culture to students (Lidi et al., 2020; Ngurah et al., 2019). Local wisdombased learning can shape students' character to have an excellent attitude to the surrounding environment, especially in certain learning materials such as social studies subjects about mutual respect and social science (Budiwibowo, 2016; Joyo, 2018). One of them is a social care character that needs to be instilled in elementary school-aged children to have an excellent social spirit towards their surroundings using electronic modules.

The electronic module is used as a learning medium and a learning guide for a subject that is coupled with technology (Astalini et al., 2019; Elder et al., 2019). Based on the existing track record of having teachers apply electronic modules as teaching materials, it becomes easier for teachers to manage technology (Astra et al., 2020; Darmaji, Kurniawan, et al., 2019; Yulando et al., 2019).Technology, if applied to the application of the module, gives students a new learning color. Technology-based will provide exciting learning (Handayani et al., 2021; Seruni et al., 2020). In addition to the ease of running and operating technology, meaningful learning for the teachers and students. The purpose of using the module as teaching material is that the character in students will be formed. Many previous studies have discussed teaching materials that are effective and efficient in learning. The findings of previous studies also stated that E-modules could help students learn (Irwansyah et al., 2017; Rasmussen et al., 2020). Other research also states that E-modules make it easier for students to understand learning to improve student learning outcomes (Hadiyanti et al., 2021; Nisa et al., 2020; Susanti et al., 2020). This study applies an electronicbased module to see the character of students. Therefore, the purpose of this study was to analyze the relationship in the implementation of the electronic module based on Ngubat Padi's local wisdom on the social care character of students. As well as knowing the relationship between the indicators of the social care character of students when implementing local wisdom-based electronic modules. It is hoped that the E-module can help students improve the character of social care.

\section{METHOD}

This research is quantitative research. Quantitative research is a research method used to examine data collection using research instruments. Statistical data analysis is quantitative and a certain population 
or sample. This research uses an associative approach, which is connecting research. The population in this study is the total number of fifth-grade students at SD Negeri 76/I Sungai Buluh. The samples used were all students of class $\mathrm{V}$, totaling 30 people. In determining the sample, a sampling technique was used, namely total sampling, in which the technique for determining the sample was taken from the large population. The researcher's criteria for using total sampling is the number of population that is less than 100 . The research instrument uses questionnaires and interviews, and interviews are questions and answers between information seekers and resource persons who understand a good thing with little or small data collection techniques. The interviews used were short questions, with a total of 15 questions. Interviews were also conducted with students to determine student responses to the application of electronic modules based on Ngubat Padi's local wisdom. The questionnaire was used in a student response questionnaire and indicators of social care character, with several valid questions, 16 items. The reliability is calculated using the formula Cronbach alpha. After the instrument was tested and analyzed for reliability, the reliability coefficient of the politeness questionnaire was 0.680 , and for mutual help, it was 0.610 , so that it can be concluded that the instrument is reliable. The form of the questionnaire used is a closed questionnaire. That is, for each question or statement, several optional answers have been provided for respondents to choose from using the Likert category of a five rating scale. Likert scale with the type of scale strongly agree (SS), agree (S), not sure $(\mathrm{N})$, disagree (TS), and strongly disagree (STS). On each question that has a positive value in an instrument that has a value of: $\mathrm{SS}=5, \mathrm{~S}=4, \mathrm{~N}=3, \mathrm{TS}=2$, and $\mathrm{STS}=1$. The score is reversed for the value on the negative item.

Table 1. Student Response Questionnaire Grid

\begin{tabular}{cllc}
\hline No & Assessment Aspect & \multicolumn{1}{c}{ Statement } & Number of Items \\
\hline 1 & Material & The material is the same as the existing & 4 \\
& & learning & 3 \\
2 & Module Contents & Structured module content & 4 \\
3 & Module view & Attractive module display & 5 \\
4 & Module language & Easy to understand & 4 \\
\hline & & Provide clear information & $\mathbf{1 6}$ \\
\hline
\end{tabular}

Table 2. Social Care Character Questionnaire Grid

\begin{tabular}{lllc}
\hline No & Assessment Aspect & \multicolumn{1}{c}{ Statement } & $\begin{array}{c}\text { Number of } \\
\text { Items }\end{array}$ \\
\hline 1 & Politeness & Speak good words & 4 \\
2 & Mutual respect & Respect other people's opinion & 3 \\
3 & Greet & Say hello to teachers and friends wherever it is & 4 \\
4 & Help each other & Helping a friend who is in trouble & 5 \\
& & Help someone who needs help & 4 \\
\hline & & Total & $\mathbf{1 6}$ \\
\hline
\end{tabular}

Electronic module validation is the validation of several experts, namely linguists, media experts, material experts, and practitioner experts. The four experts went through the stage of filling out the validation sheet, which was sourced from the modified results of the 2016 BSNP source. The module validation was aimed at seeing whether or not the electronic module was applied to classroom learning. The instrument for assessing the validity of the electronic module based on local wisdom is arranged in the form of a Likert scale with a positive statement. The data from the responses of several experts were analyzed in the following two steps, namely firstly adding up the total score of each expert for all indicators and secondly giving the validity value by using the method, the total score obtained was divided by the maximum score and then multiplied by $100 \%$. The analysis of the validity of the module was carried out using descriptive statistics, the results of which were depicted through graphs. The validation score becomes a value with a range of $0-100$. The results obtained are then interpreted with the following criteria. Data analysis in this study uses descriptive statistics and inferential statistics. Descriptive statistical information is statistical information used to analyze data by describing or describing the data collected, without the intention of drawing conclusions that can be applied in general or generalizations (Riduwan, 2013). This study uses descriptive statistics using the maximum, minimum, and mean values. Whereas inferential statistics is a statistical calculation used to analyze data from a sample, the results will be generalized or concluded for the population from which the sample is taken. 
Table 5. Criteria For Validation Of The Modified Likert Scale Electronic Module

\begin{tabular}{cc}
\hline Percentage & Criteria \\
\hline $0-20$ & Not feasible \\
$21-40$ & less worthy \\
$41-60$ & Decent enough \\
$61-80$ & Worthy \\
$81-100$ & Very Worthy \\
\hline
\end{tabular}

\section{RESULT AND DISCUSSION}

\section{Result}

The application of electronic modules in classroom learning through the validation of several media, language, material, and practitioner experts with the results obtained is at a percentage of $61-80 \%$ with a decent category. Therefore, the electronic module based on the local wisdom of Ngubat Padi is feasible to be used as teaching material during learning at school. Besides being validated by experts, the module can instill social care characters in students because the local wisdom used is closely related to the values of social care characters. From the character of social care, several indicators are used as essential aspects in the character of social care. Indicators of the social care character of students are used to see the relationship with the use of electronic modules during learning. Eighteen indicators of the student's character are the value of social care character. The value of this social care character has a significant relationship with student learning outcomes obtained. It means that the value of social care character has a significant correlation with student learning outcomes. In this study, the character of social care is divided into several indicators. Based on the results of data analysis, it can be shown that the table above shows the results of social care based on indicators of courtesy and mutual help. The categories of students by looking at the indicators of the manners of students at school: the category of lousy character students as much as $3.33 \%$ ( 1 out of 30 students), students with wrong categories as much as $10.00 \%$ ( 3 out of 30 students), students with categories enough as much as $26.66 \%$ (8 out of 30 students), students with good category as much as $36.66 \%$ ( 11 out of 30 students), and students with outstanding category as much as $23.35 \%$ (7 out of 30 students). Meanwhile, based on the character indicator scale, the data results above show that the data obtained is a mean value of 65.8, a maximum of 71, and a minimum of 56 .

Students by looking at the indicators of helping each other at school: the category of lousy student character is $6.67 \%$ ( 2 out of 30 students), students with the lousy category are $13.33 \%$ (4 out of 30 students), students with lousy category $23.33 \%$ ( 7 out of 30 students), $33.33 \%$ good category (10 out of 30 students), and $23.35 \%$ very good ( 7 out of 30 students). Meanwhile, based on the character indicator scale, the data above shows that the data obtained is a mean value of 84.00. A maximum of 91 , and a minimum of 62. Students' response by looking at the application of an electronic module based on Ngubat Padi local wisdom indicators of courtesy and helping each other is good as many as students in the excellent category of students as many as $33.33 \%$ (10 of 30 students). And students with very good categories, as many as $23.35 \%$ ( 7 of 30 students). While the response to the character indicator, please help students in the category of $36.66 \%$ ( 11 out of 30 students). And students in the very good category as many as $23.35 \%$ ( 7 of 30 students). From the results of the two responses, the responses given by students on the application of the module are included in the good category. From the normality test, it can be seen that the significant value resulted from the normality test. Based on Kolmogrof-Smirnoff from two independent samples. sig value $>0.05$. The normality value of 0.382 in the sig normality value means that the existing data is normal because the sig value is $>0.05$. In addition to the normality test, a linearity test was carried out on the data with a significant value resulting from the linearity test above the sig value $>0.05$. Then the data was said to be linear. The correlation between the two indicators of social care character, namely courtesy and mutual help with student responses, is 0.969 . The relationship between the two indicators is strong, with a probability value of $0.000<0.005$, so it can be concluded that both indicators are significant. It can be concluded that there is a relationship between the indicators of courtesy and mutual help with students' response to the application of the electronic module based on Ngubat Padi local wisdom with an R-value of 0.969 and a positive value.

\section{Discussion}

The social care character indicator of polite students becomes the first benchmark to see the social care character. Politeness is generally a rule of life that results from the interaction of social groups (Djuwita, 2017; Putrihapsari \& Dimyati, 2021). Students' manners at school and in their lives (Fitriani, 2019; Nurtanto et al., 2019). The teacher can take advantage of the students' trust in him. Teachers can 
apply several ways and methods to implement manners to students, for example, by implementing an electronic module to see student manners at school (Hartini, S. et al., 2018; Imamah \& Susanti, 2021; Marhayani, 2016). In addition to manners, another indicator of caring social character is to help (Serbin et al., 2020; Sulatri et al., 2019). Supported by the results obtained from descriptive statistics on the indicators of helping to show a positive attitude when implementing the electronic module and seen from the results of data analysis that $33.3 \%$ of students or 10 out of a total of 30 students were in a suitable category. It is also supported by the mean result of 84.00 which, the range is a good category. Please help is expected not to discriminate against who will be helped, regardless of class, rank, religion, race, age, and gender (Serbin et al., 2020; Supriyadi et al., 2019). Regardless of class, class, religion, race, age, and gender, please do not expect help from people who get help. Helping needs to be done or applied in everyday life, both at home, at school, and in the community (Abu Bakar et al., 2018; Rosala \& Budiman, 2020). Indicators of helping students refer to students' attitudes towards their social environment. Another way to help is to help each other in the social life around us (Madleňák, 2015; Muthuprasad et al., 2021).

From the data obtained, it was concluded that the electronic module technically got an excellent category. Thus, the electronic module was judged from the language, media, material, and practitioners it was feasible to use as a learning resource in a lesson. The electronic module is considered to have a beautiful appearance, the material presented is systematic so that it is easy for students to understand, provides higher learning interest, the character of students can be formed according to the material in the module (Astalini et al., 2019; Hamid et al., 2021; Syahroni et al., 2016). Previous research applies electronic-based modules to see student learning outcomes. Research conducted assesses that the application of electronic modules is considered more practical and efficient (Fisnani et al., 2020; Ningsih \& Mahyuddin, 2021; Sadimin Sadimin et al., 2017). The position of this study with previous research is the electronic module as a form of measuring student learning outcomes and student character as a variable in the study. The novelty of this research is on the variables studied, namely indicators of social care character. In class V, theme 8, Sub-theme 1, Learning 3, using the Kvisotf Flipbook maker technology device, the first character is politeness, and the second is helping each other. These two indicators are seen after applying the electronic module in this study to see the relationship between the application of the electronic module and the indicators of social care character. Whereas in previous studies, many researched the relationship with social care characters, not on character indicators. The implication of the research on the relationship of social care characters to learning responses is that they can be used as teaching materials in learning for fifth-grade students in Theme 8 and Sub-theme 1 of learning 3 in finding out the diversity of local wisdom in the local province, Jambi Province, to be precise. The implication given to students is to positively impact student learning outcomes because students will more easily access and absorb learning materials. At the same time, a teacher can find or develop teaching materials other than the teaching materials provided by the school. In addition, it becomes a teaching material that suits the needs of students and can be used as a source of independent learning. The limitations of this study are that this electronic module is limited to essential competencies for class $\mathrm{V}$, theme 8 , sub-theme 3, learning 3 , which is based on the local wisdom of Ngubat Padi. This research recommends that electronic modules based on Ngubat Padi's local wisdom be applied to the character of environmental care, social care, and discipline.

\section{CONCLUSION}

The application of electronic modules in classroom learning through expert validation gets a proper qualification. The responses given by students on the application of the module were included in the excellent category. There is a relationship between the indicators of courtesy and mutual help with students' responses to the application of electronic modules based on Ngubat Padi's local wisdom. The character of social care will grow well if the student's environment also encourages it.

\section{REFERENCES}

Abu Bakar, K. A., Noor, I. H. M., \& Dan Widodo. (2018). Nurturing nationalism character valuesat the primary schools in jayapura, papua. Cakrawala Pendidikan, 37(1), 42-56. https://doi.org/10.21831/cp.v37i1.13616.

Aina, \& Tuti. (2020). Improving Teacher Performance In Classroom Learning Process Through Collaborative Educational Supervisions In Elementary Schools. Primary Jurnal Pendidikan Guru Sekolah Dasar, 9(2). https://doi.org/10.33578/jpfkip.v9i2.7894.

Almusawi, H. A., Durugbo, C. M., \& Bugawa, A. M. (2021). Innovation in physical education: Teachers' perspectives on readiness for wearable technology integration. Computers \& Education, 167. https://doi.org/10.1016/j.compedu.2021.104185. 
Aprilia, I., \& Suryadarma, I. G. P. (2020). E-Module of Mangrove Ecosystem (EMME): Development, Validation, and Effectiveness in Improving Students' Self-Regulated. Biosfer: Jurnal Pendidikan, 13(1), 114-129. https://doi.org/10.21009/biosferjpb.v13n1.114-129.

Asrial, Syahrial, Maison, M., Kurniawan, D. A., \& Piyana, S. O. (2020). Ethnoconstructivism E-Module to Improve Perception, Interest, And Motivation of Students in Class V Elementary School. Jurnal Pendidikan Indonesia, 9(1), 30-41. https://doi.org/10.23887/jpi-undiksha.v9i1.19222.

Astalini, A., Darmaji, D., Kurniawan, W., Anwar, K., \& Kurniawan, D. A. (2019). Effectivenes of Using E-Module and E-Assessment. International Journal of Interactive Mobile Technologies (IJIM), 13(09), 21-39. https: //doi.org/10.3991/ijim.v13i09.11016.

Astra, I. M., Raihanati, R., \& Mujayanah, N. (2020). Development of Electronic Module Using Creative Problem-Solving Model Equipped with Hots Problems on The Kinetic Theory of Gases Material. Jurnal Penelitian \& Pengembangan Pendidikan Fisika, 6(2), 181-194. https: //doi.org/10.21009/1.06205.

Astuti, M., Arifin, Z., Mutohhari, F., \& Nurtanto, M. (2021). Competency of Digital Technology: The Maturity Levels of Teachers and Students in Vocational Education in Indonesia. Journal of Education Technology, 5(2), 254-262. https://doi.org/10.23887/jet.v5i3.35108.

Aufa, M. N., Rusmansyah, R., Hasbie, M., Jaidie, A., \& Yunita, A. (2021). The Effect of Using e-module Model Problem Based Learning (PBL) Based on Wetland Environment on Critical Thinking Skills and Environmental Care Attitudes. Jurnal Penelitian Pendidikan IPA, 7(3), 401-407. https://doi.org/10.29303/jppipa.v7i3.732.

Baker, E. R., D’Esterre, A. P., \& Weaver, J. P. (2021). Executive function and Theory of Mind in explaining young children's moral reasoning: A Test of the Hierarchical Competing Systems Model. Cognitive Development, 58. https://doi.org/10.1016/j.cogdev.2021.101035.

Bakırcı, H., Bilgin, A. K., \& Simsek, A. (2011). The effects of simulation technique and worksheets on formal operational stage in science and technology lessons. Procedia - Social and Behavioral Sciences, 15. https://doi.org/10.1016/j.sbspro.2011.03.311.

Başöz, T., \& Çubukçu, F. (2014). Pre-service EFL Teacher's Attitudes towards Computer Assisted Language Learning (CALL). Procedia - Social and Behavioral Sciences, 115. https://doi.org/10.1016/j.sbspro.2014.01.253.

Bravo, E. R., Santana, M., \& Rodon, J. (2015). Information systems and performance: The role of technology, the task and the individual. Behaviour and Information Technology, 34(3), 247-260. https://doi.org/10.1080/0144929X.2014.934287.

Budiwibowo, S. (2016). Membangun Pendidikan Karakter Generasi Muda Melalui Budaya Kearifan Lokal Di Era Global. Premiere Educandum: Jurnal Pendidikan Dasar Dan Pembelajaran, 3(01), 39-49. https://doi.org/10.25273/pe.v3i01.57.

Chauhan, S. (2017). A meta-analysis of the impact of technology on learning effectiveness of elementary students. Computers \& Education, 105, 14-30. https: //doi.org/10.1016/j.compedu.2016.11.005.

Darmaji, Astalini, Kurniawan, D. A., Parasdila, H., Iridianti, Susbiyanto, Kuswanto, \& Ikhlas, M. (2019). EModule based problem solving in basic physics practicum for science process skills. International Journal of Online and Biomedical Engineering, 15(15), 4-17. https://doi.org/10.3991/ijoe.v15i15.10942.

Darmaji, D., Kurniawan, D. A., Astalini, A., Kurniawan, W., Anwar, K., \& Lumbantoruan, A. (2019). Students' perceptions of electronic's module in physics practicum. Journal of Education and Learning (EduLearn), 13(2), 288-294. https://doi.org/10.11591/edulearn.v13i2.13005.

Djuwita, P. (2017). Pembinaan Etika Sopan Santun Peserta Didik Kelas V Melalui Pembelajaran Pendidikan Kewarganegaraan Di Sekolah Dasar Nomor 45 Kota Bengkulu. Jurnal PGSD, 10(1), 27-36. https://doi.org/10.33369/pgsd.10.1.27-36.

Elder, J. J., Franco, K. A., Gulley, S. L., Hughes, C. T., \& Infanti, L. M. (2019). Implementation of Required Electronic Learning Modules to Enhance Nursing Pharmacotherapy Knowledge of Select Hematopoietic Stem Cell Transplant Topics. Biology of Blood and Marrow Transplantation, 25(3), S303. https://doi.org/10.1016/j.bbmt.2018.12.655.

Eugenia, Raymond, \& Leung, W. N. (2013). Ready for 21st-century Education - Pre-service Music Teachers Embracing ICT to Foster Student-centered Learning. Procedia - Social and Behavioral Sciences, 73. https://doi.org/10.1016/j.sbspro.2013.02.047.

Fisnani, Y., Utanto, Y., \& Ahmadi, F. (2020). The Development of E-Module for Batik Local Content in Pekalongan Elementary School. Innovative Journal of Curriculum and Educational Technology, 9(1), 40-47. https://doi.org/10.15294/IJCET.V9I1.35592.

Fitriani, S. (2019). Pendidikan Karakter Sebagai Upaya Menciptakan Akhlak Mulia Siswa Sekolah Dasar. ELSE (Elementary School Education Journal) : Jurnal Pendidikan Dan Pembelajaran Sekolah Dasar, 
3(2), 229-238. https://doi.org/10.30651/else.v3i2.3011.

Fu, Q.-K., Lin, C.-J., Hwang, G.-J., \& Zhang, L. (2019). Impacts of a mind mapping-based contextual gaming approach on EFL students' writing performance, learning perceptions and generative uses in an English course. Computers \& Education, 137. https://doi.org/10.1016/j.compedu.2019.04.005.

Hadiyanti, N. F. D., Hobri, Prihandoko, A. C., Susanto, Murtikusuma, R. P., Khasanah, N., \& Maharani, P. (2021). Development of mathematics e-module with STEM-collaborative project based learning to improve mathematical literacy ability of vocational high school students. Journal of Physics: Conference Series, 1839(1). https://doi.org/10.1088/1742-6596/1839/1/012031.

Hamid, S. N. M., Lee, T. T., Taha, H., Rahim, N. A., \& Sharif, A. M. (2021). E-Content Module For Chemistry Massive Open Online Course (Mooc): Development And Students' Perceptions. Journal of Technology and Science Education, 11(1), 67-92. https://doi.org/10.3926/jotse.1074.

Handayani, D., Elvinawati, E., Isnaeni, I., \& Alperi, M. (2021). Development Of Guided Discovery Based Electronic Module For Chemical Lessons In Redox Reaction Materials. International Journal of Interactive Mobile Technologies (IJIM), 15(07), 94. https://doi.org/10.3991/ijim.v15i07.21559.

Hartini, S., S., Firdausi, Misbah, \& Sulaeman. (2018). The Development of Physics Teaching Materials Based on Local Wisdom to Train Saraba Kawa Characters. Jurnal Pendidikan IPA Indonesia, 7(2). https://doi.org/10.15294/jpii.v7i2.14249.

Herawati, N. S., \& Muhtadi, A. (2018). Pengembangan Modul Elektronik (E-Modul) Interaktif Pada Mata Pelajaran Kimia kelas XI SMA. Jurnal Inovasi Teknologi Pendidikan, 5(2), 180-191. https://doi.org/10.21831/jitp.v5i2.15424.

Ilmi, R., Arnawa, I. M., Yerizon, \& Bakar, N. N. (2021). Development of an Android-Based for Math E-Module by using Adobe Flash Professional CS6 for Grade X Students of Senior High School. Journal of Physics: Conference Series, 1742(1). https://doi.org/10.1088/1742-6596/1742/1/012026.

Imamah, N., \& Susanti, L. Y. (2021). Development of Sigil-Based Additives and Addictive Substances Teaching Chart for Junior High School Students: Alternative Learning Resources During a Pandemic. INSECTA: Integrative Science Education and Teaching Activity Journal, 2(1), 15-30. https://doi.org/10.21154/insecta.v2i1.2464.

Irwansyah, Lubab, Farida, \& Ramdhani. (2017). Designing Interactive Electronic Module in Chemistry Lessons F S. International Conference on Mathematics and Science Education (ICMScE), 895(1), 1-7. https://doi.org/10.1088/1742-6596/895/1/012009.

Joyo, A. (2018). Gerakan Literasi Dalam Pembelajaran Bahasa Indonesia Berbasis Kearifan Lokal Menuju Siswa Berkarakter. Jurnal Kajian Bahasa, Sastra Dan Pengajaran (KIBASP), 1(2). https://doi.org/10.31539/kibasp.v1i2.193.

Kaplan, D. E. (2018). Piagetian Theory in Online Teacher Education. Scientific Research Publishing, 9(6). https://doi.org/10.4236/ce.2018.96061.

Komikesari, H., Mutoharoh, M., Dewi, P. S., Utami, G. N., Anggraini, W., \& Himmah, E. F. (2020). Development of e-module using flip pdf professional on temperature and heat material. Journal of Physics: Conference Series, 1572(1). https://doi.org/10.1088/1742-6596/1572/1/012017.

Kratz, F., Patzina, A., Kleinert, C., \& Dietrich, H. (2019). Vocational education and employment: Explaining cohort variations in life course patterns. Social Inclusion, 7(3), 224-253. https://doi.org/10.17645/si.v7i3.2045.

Lidi, M. W., Ningsih, \& Dhiki, Y. Y. (2020). Identifikasi Potensi Kearifan Lokal Masyarakat Golewa Kabupaten Ngada sebagai Upaya Pengembangan di Bidang Pendidikan. OPTIKA: Jurnal Pendidikan Fisika, 4(1), 21-29. https://doi.org/10.37478/optika.v4i1.332.

Linda, R., Herdini, Sulistya, I., \& Putra, T. P. (2018). Interactive E-Module Development through Chemistry Magazine on Kvisoft Flipbook Maker Application for Chemistry Learning in Second Semester at Second Grade Senior High School. Journal of Science Learning, 2(1), 21-25. https://doi.org/10.17509/jsl.v2i1.12933.

Logan, R. M., Johnson, C. E., \& Worsham, J. W. (2021). Development of an E-learning Module to Facilitate Student Learning and Outcomes. Teaching and Learning in Nursing, 16(2), 139-142. https://doi.org/10.1016/j.teln.2020.10.007.

Lynch, M., Sage, T., Hitchcock, L. I., \& Sage, M. (2021). A heutagogical approach for the assessment of Internet Communication Technology (ICT) assignments in higher education. International Journal of Educational Technology in Higher Education, 18(1). https://doi.org/10.1186/s41239-021-00290$\mathrm{X}$.

Madleňák, R. et al. (2015). Designing a Social Network to Support E-learning Activities at the Department of Communications, University of Žilina. Procedia - Social and Behavioral Sciences, 176, 103-110. https://doi.org/10.1016/j.sbspro.2015.01.449.

Mahmoodi, M., Rashtchi, M., \& Abbasian, G. R. (2019). Evaluation of in-service teacher training program in 
iran: Focus on the Kirkpatrick model. Education and Self Development, 14(4), 20-38. https://doi.org/10.26907/esd14.4.03.

Marhayani, D. A. (2016). Development of Character Education Based on Local Wisdom in Indegenous People Tengahan Sedangagung. JETL (Journal Of Education, Teaching and Learning), 1(2), 66. https://doi.org/10.26737/jetl.v1i2.40.

Maulana, H. A. (2021). Psychological Impact of Online Learning during the COVID-19 Pandemic: A Case Study on Vocational Higher Education. Indonesian Journal of Learning Education and Counseling, 3(2), 130-139. https://doi.org/10.31960/ijolec.v3i2.833.

Mehrtash, M., Yuen, T., \& Balan, L. (2019). Implementation of Experiential Learning for Vehicle Dynamic in Automotive Engineering: Roll-over and Fishhook Test. Procedia Manufacturing, 32. https://doi.org/10.1016/j.promfg.2019.02.284.

Müller, F. A., \& Wulf, T. (2020). Technology-supported management education: a systematic review of antecedents of learning effectiveness. International Journal of Educational Technology in Higher Education, 17(1). https://doi.org/10.1186/s41239-020-00226-x.

Muthuprasad, T., Aiswarya, S., Aditya, K. S., \& Jha, G. K. (2021). Social Sciences \& Humanities Open Students' perception and preference for online education in India during COVID -19 pandemic. Social Sciences \& Humanities Open, 3(1), 100101. https://doi.org/10.1016/j.ssaho.2020.100101.

Ngurah, G., Nugraha, S., Tegeh, I. M., \& Sudarma, I. K. (2019). Pengembangan Multimedia Interaktif Matematika Berorientasi Kearifan Lokal Kelas 3 Sekolah Dasar Negeri 1 Paket Agung. Jurnal Edutech, 7(1), 12-22.

Ningsih, S. Y., \& Mahyuddin, N. (2021). Desain E-Module Tematik Berbasis Kesantunan Berbahasa Anak Usia Dini di Taman Kanak-Kanak. Jurnal Obsesi : Jurnal Pendidikan Anak Usia Dini, 6(1), 137-149. https://doi.org/10.31004/obsesi.v6i1.1217.

Nisa, W. L., Ismet, I., \& Andriani, N. (2020). Development of E-Modules Based on Multi-representations in Solid-State Physics Introductory Subject. Berkala Ilmiah Pendidikan Fisika, 8(2), 73. https://doi.org/10.20527/bipf.v8i1.7690.

Nurtanto, M., Sofyan, H., Fawaid, M., \& Rabiman, R. (2019). Problem-based learning (PBL) in industry 4.0: Improving learning quality through character-based literacy learning and life career skill (LL-LCS). Universal Journal of Educational Research, 7(11), 2487-2494. https://doi.org/10.13189/ujer.2019.071128.

Omotayo, F. O., \& Haliru, A. (2020). Perception of Task-Technologyfit of Digital Library among Undergraduates in Selected Universities in Nigeria. The Journal of Academic Librarianship, 46(1), 102097. https://doi.org/10.1016/j.acalib.2019.102097.

Oswald-Egg, M. E., \& Renold, U. (2021). No experience, no employment: The effect of vocational education and training work experience on labour market outcomes after higher education. Economics of Education Review, 60. https://doi.org/10.1016/j.econedurev.2020.102065.

Perdana, Sarwanto, Sukarmin, S., \& Sujadi, I. (2017). Development of E-Module Combining Science Process Skills And Dynamics Motion Material To Increasing Critical Thinking Skills And Improve Student Learning Motivation Senior High School. International Journal of Science and Applied Science, 1(1), 45-54. https://doi.org/10.20961/ijsascs.v1i1.5112.

Putrihapsari, R., \& Dimyati, D. (2021). Penanaman Sikap Sopan Santun dalam Budaya Jawa pada Anak Usia Dini. Jurnal Obsesi : Jurnal Pendidikan Anak Usia Dini, 5(2). https://doi.org/10.31004/obsesi.v5i2.1022.

Raharjo, M. W. C., Suryati, S., \& Khery, Y. (2017). Pengembangan E-Modul Interaktif Menggunakan Adobe Flash Pada Materi Ikatan Kimia Untuk Mendorong Literasi Sains Siswa. Hydrogen: Jurnal Kependidikan Kimia, 5(1), 8. https://doi.org/10.33394/hjkk.v5i1.102.

Raja, R., \& Nagasubramani, P. C. (2018). Impact of modern technology in education. Journal of Applied and Advanced Research, 3(S1), 33. https://doi.org/10.21839/jaar.2018.v3is1.165.

Rasmussen, E., Goddard, A. G., \& Bayer, D. K. (2020). Use of electronic learning modules can improve medical trainee knowledge regarding anaphylaxis diagnosis and treatment. Annals of Allergy, Asthma \& Immunology, 124(3). https://doi.org/10.1016/j.anai.2019.12.018.

Riduwan. (2013). Dasar-dasar Statistika. Alfabeta.

Rosala, D., \& Budiman, A. (2020). Local Wisdom-based Dance Learning: Teaching Characters to Children through Movements. Mimbar Sekolah Dasar, 7(3), 304-326. https://doi.org/10.17509/mimbarsd.v7i3.28185.

Sadimin Sadimin, Wahyu Hardyanto, \& Slamet, A. (2017). Developing An E-Module-Based Classroom Action Research Management Training Model For Teachers High School. International Journal of Education and Research, 5(2), 79-90. https://doi.org/10.15294/jed.v5i3.18123.

Sajnani, N., \& Mayor, C. et al. (2020). Aesthetic presence: The role of the arts in the education of creative arts 
therapists in the classroom and online. Arts in Psychotherapy, 69(February), 101668. https://doi.org/10.1016/j.aip.2020.101668.

Serbin, K. S., Robayo, B. J. S., Truman, J. V., Watson, K. L., \& Wawro, M. (2020). Characterizing quantum physics students' conceptual and procedural knowledge of the characteristic equation. The Journal of Mathematical Behavior, 58. https://doi.org/10.1016/j.jmathb.2020.100777.

Seruni, R., Munawaroh, S., Kurniadewi, F., \& Nurjayadi, M. (2020). Implementation of e-module flip PDF professional to improve students' critical thinking skills through problem based learning. Journal of Physics: Conference Series, 1521(4), 1-6. https://doi.org/10.1088/1742-6596/1521/4/042085.

Sulatri, D. K., Dharsana, I. K., \& Suarni, N. K. (2019). Effectiveness of behavioral ivan pavlov conselvation the using modeling techniques to increase characters to completely complete duties through leason study. Konselor, 8(1). https://doi.org/10.24036/0201981103974-0-00.

Supriyadi, E., Zamtinah, Soenarto, S., \& Hatmojo, Y. I. (2019). A character-based assessment model for vocational high schools. Cakrawala Pendidikan, 38(2), 269-280. https://doi.org/10.21831/cp.v38i2.24099.

Susanti, N., Yennita, Y., \& Azhar, A. (2020). Development of Contextual Based Electronic Global Warming Modules Using Flipbook Applications as Physics Learning Media in High Schools. Journal of Educational Sciences, 4(3), 541. https: //doi.org/10.31258/jes.4.3.p.541-559.

Syahroni, M. W., Dewi, N. R., \& Kasmui. (2016). The Effect of Using Digimon (Science Digital Module) with Scientific Approach at the Visualization of Students' Independence and Learning Results. Jurnal Pendidikan IPA Indonesia, 5(1), 116-122. https://doi.org/10.15294/jpii.v5i1.5800.

Tajvidi, M., Ghiyasvandian, S., \& Salsali, M. (2014). Probing concept of critical thinking in nursing education in Iran: A concept analysis. Asian Nursing Research, 8(2), 158-164. https://doi.org/10.1016/j.anr.2014.02.005.

Tondeur, J., Scherer, R., Baran, E., Siddiq, F., Valtonen, T., \& Sointu, E. (2019). Teacher educators as gatekeepers: Preparing the next generation of teachers for technology integration in education. British Journal of Educational Technology, 50(3), 1189-1209. https://doi.org/10.1111/bjet.12748.

Winther-Lindqvist, D. A. (2020). Caring well for children in ECEC from a wholeness approach - The role of moral imagination. Learning, Culture and Social Interaction, 1. https://doi.org/10.1016/j.lcsi.2020.100452.

Yulando, S., Sutopo, S., \& Franklin Chi, T. (2019). Electronic Module Design and Development: An Interactive Learning. American Journal of Educational Research, 7(10), 694-698. https://doi.org/10.12691/education-7-10-4. 